\title{
PHYTOCHEMICAL SCREENING AND ANTIOXIDANT POTENTIAL OF PTEROCARPUS SANTALINUS L.F. PLANT PARTS
}

\begin{abstract}
BHARATHI $B^{1 *}$, PRASAD NBL ${ }^{2}$
${ }^{1}$ Department of Chemistry, Research scholar, Jawaharlal Nehru Technological University, Ananthapuramu, Andhra Pradesh, India. ${ }^{2}$ Department of Senior Chemical Engineer (Retd.), Oil Technological Research Institute, Jawaharlal Nehru Technological University, Ananthapuramu, Andhra Pradesh, India. Email: bharathiotri@gmail.com
\end{abstract}

Received: 18 September 2020, Revised and Accepted: 08 January 2021

ABSTRACT

Objective: Oxidation is a normal process in many biological metabolisms in living beings, but in this technology era radiation, pollution, irregular life style, and unhealthy diet leads to excessive oxidation resulting in imbalance between antioxidants and free radicals in body called oxidative stress, which may result in cardiac problems, diabetes, and carcinogenic diseases. Therefore, exploration of natural antioxidants in flora and fauna is becoming important. In this motive a phytochemical study was taken up on various parts of Pterocarpus santalinus L.f. plant belonging to Leguminosae family to check the presence of antioxidant activity (AA).

Methods: The leaves, flowers, fruits, and roots of this plant were extracted with six different organic solvents from polar to non-polar. To estimate the AA of these extracts, four types of antioxidant tests were done on them, namely, $\alpha, \alpha$ - Diphenyl - $\beta$ - Picryl - Hydrazyl free radical scavenging activity (DPPH RSA) assay, relative reducing power (RRP) assay, Ferric thiocyanate (FTC) assay, and $\beta$ - carotene bleaching assay with Butylated Hydroxy Toluene (BHT) as synthetic standard.

Results: In extraction, Me extracts showed highest yields. Qualitative phytochemical screening has revealed many bioactive components in the Me and Et extracts of plant parts majorly. In DPPH RSA assay, Me extracts of leaves showed RSA activity almost equal to reference standard. In RRP assay, Me floral extracts showed AA higher than standard. FTC and $\beta$ - Carotene assays showed that Me sample extracts possess good AA than BHT. In FTC assay, lower absorption values specify high AA, whereas in $\beta$ - Carotene assay, high absorption values indicate high AA of the sample extracts.

Conclusion: Among six solvents methanol showed highest extraction efficiency and also revealed highest number of phytochemicals in its extracts. These four AA assays revealed that the methanol extracts of all plant parts, that is., leaves, roots, fruits, and flowers possess better AA compared other solvent extracts.

Keywords: Pterocarpus santalinus L.f., Phytochemical screening, Antioxidant activity, $\alpha, \alpha$ - Diphenyl - $\beta$ - picryl - hydrazyl radical scavenging activity assay, Relative reducing power assay, Ferric thiocyanate assay, $\beta$ - carotene bleaching assay, Butylated Hydroxy Toluene.

(C) 2021 The Authors. Published by Innovare Academic Sciences Pvt Ltd. This is an open access article under the CC BY license (http://creativecommons.org/ licenses/by/4.0/) DOI: http://dx.doi.org/10.22159/ajpcr.2021v14i3.39808. Journal homepage: https://innovareacademics.in/journals/index.php/ajpcr

\section{INTRODUCTION}

With many limitations, the advanced contemporary sciences are now in retrospection of ancient conventional medicines and methods. Even people in sophisticated countries are changing their life style toward traditional comportment for hale and hearty longevity. Due to these changes, our Indian ayurvedic medicines and yogic practices are becoming prominent currently. Phytochemicals present in plants acts as natural curers for many diseases and health ailments [1]. These phytochemicals have antioxidant [2], antifungal [3], and antimicrobial [4] potentials naturally. The secondary metabolites which show antioxidant activity (AA) include polyphenols [5], ascorbic acid [6], anthocyanins [7], and flavonoids [8]. Pterocarpus santalinus L.f. is an ancient traditional medicinal plant in India, with many medicinal values. A preliminary phytochemical analysis was done on leaves, fruits, flowers, and roots extracts of this plant with six different solvents, namely, methanol (Me), ethanol (Et), ethyl acetate (EA), chloroform (Ch), carbon tetrachloride (CC), and $\mathrm{n}$ - hexane (He), which revealed the presence of several phytochemicals. Four different antioxidant assays were done on these extracts in different concentrations to assess their AA.

\section{METHODS}

\section{Collection}

$P$. santalinus L.f plant leaves, flowers, fruits, and roots were collected from Seshachalam hills, Tirupati, Andhra Pradesh, India, which were shown in Fig. 1. Authentication of the plant was done by Prof B. Ravi
Prasad Rao, the plant sample was deposited in herbarium of Botany Dept. possessing a serial no-48799 in Sri Krishnadevaraya University, Ananthapuramu, Andhra Pradesh, India.

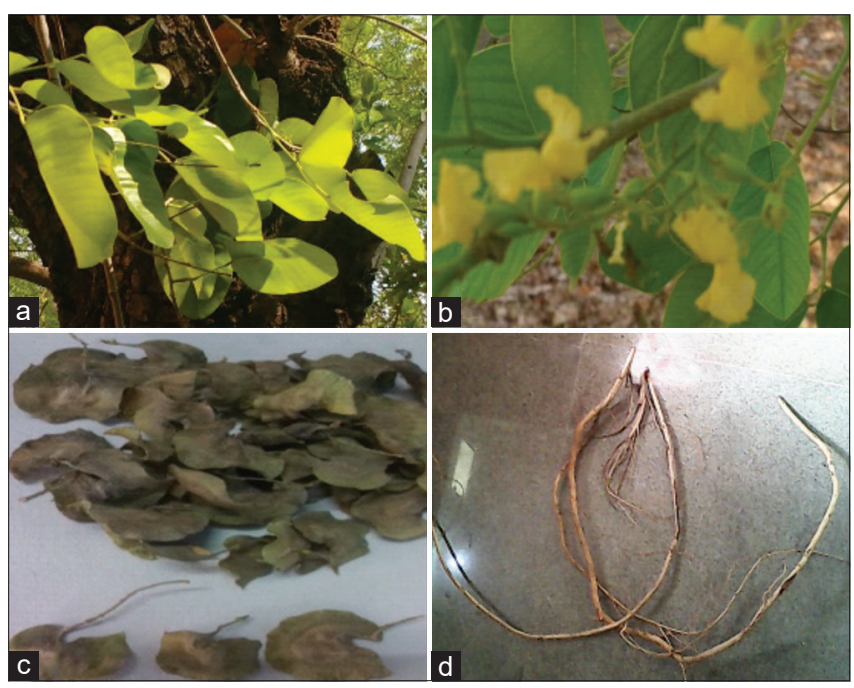

Fig. 1: Collected plant parts of Pterocarpus santalinus L.f. (a) Leaves (b) flowers (c) fruits (d) roots 


\section{Extraction}

P. santalinus L.f. plant parts were cleaned with fresh water thoroughly and dried up in shade completely, then pulverized into powder. Five hundred grams of powder of each plant part were extracted with 1500 $\mathrm{ml}$ of solvent for $24 \mathrm{~h}$ with intermittent stirring. It was filtered with Whatman filter paper and the remainder was again extracted with the same solvent till the solution becomes pale in color. The solution of same solvent was pooled up and the solvent was recycled on a Heidolph Rota-evaporator below $40^{\circ} \mathrm{C}$ to give extract. Likewise each plant part was extracted with six different solvents, namely, Me, Et, Ea, Ch, CC, and He. The yields and extraction efficiencies of all solvents were shown in Table 1.

\section{Qualitative phytochemical screening [9]}

A qualitative phytochemical study was done on all solvent extracts of plant parts to identify the phytochemicals consisting and the results were presented in Table 2.

\section{AA assessments}

$\alpha, \alpha$ - Diphenyl - $\beta$ - picryl - hydrazyl (DPPH) free radical scavenging assay

DPPH assay was proposed by Von Gadow et al. [10] to assess the radical scavenging activity (RSA) of an extract. One milliliter of various concentrations $(5,10,15,20$, and $25 \mathrm{mg} / \mathrm{ml})$ of extract was prepared in Me. To $1 \mathrm{ml}$ of the sample solution, $1 \mathrm{ml}$ of $0.2 \mathrm{mM} \mathrm{DPPH} \mathrm{Me}$ solution was added and absorption was read at $517 \mathrm{~nm}$ immediately. The absorption of $2 \mathrm{ml} \mathrm{Me}$, which acts as a control was also read at $517 \mathrm{~nm}$. The mixture was then vortexed and incubated for $16 \mathrm{~min}$. The decrease in absorption was measured at $517 \mathrm{~nm}$ after $16 \mathrm{~min}$. Butylated Hydroxy Toluene (BHT) Me solution was used as standard reference. Likewise this assay was performed for six solvent extracts of all plant parts and inhibition percentages of extracts were measured and shown as a graphical representation in Fig. 2. The percentage of DPPH RSA of extract was calculated [11] as follows:

$$
\% \text { Inhibition }=\left[\left(\mathrm{A}_{\mathrm{C}(0)}-\mathrm{A}_{\mathrm{A}(\mathrm{t})}\right) / \mathrm{A}_{\mathrm{C}(0)}\right] \times 100
$$

Where $\mathrm{A}_{\mathrm{C}(0)}$ is the absorbance of control at $\mathrm{t}=0 \mathrm{~min}$, $A_{A(t)}$ is the absorbance of antioxidant at $t=16 \mathrm{~min}$.

\section{Relative reducing power (RRP) assay}

RRP assay was proposed by Oyaizu [12], which was used to evaluate the RRP of the sample. Here five concentrations $(25,50$, 100,150 , and $200 \mu \mathrm{g} / \mathrm{ml}$ ) of extract were prepared using Me. 2.5 $\mathrm{ml}$ of phosphate buffer $(0.2 \mathrm{M}, \mathrm{pH}-6.6)$ and $2.5 \mathrm{ml}$ of potassium ferric cyanide $(1 \%)$ solution was mixed with $1 \mathrm{ml}$ of extract, then incubated for $20 \mathrm{~min}$ at $50^{\circ} \mathrm{C}$. By the end of incubation, $2.5 \mathrm{ml}$ of $10 \%$ trichloroacetic acid was added and the above mixture was centrifuged at $5000 \mathrm{rpm}$ for $10 \mathrm{~min}$. One milliliter of the upper layer was added with $3 \mathrm{ml}$ of distilled water and $0.5 \mathrm{ml}$ of $0.1 \%$ ferric chloride and the absorbance was read at $700 \mathrm{~nm}$. BHT was used as standard antioxidant; the RRP of the six solvent extracts of all plant parts was assessed by this method and represented graphically in Fig. 3. The percentage of RRP of the extract was calculated using the below equation,

$$
\% \text { of RRP calculation }=\left[\left(A_{A} / A_{C}\right)-1\right] \times 100
$$

Where $\mathrm{A}_{\mathrm{A}}=$ the absorbance of antioxidant at $700 \mathrm{~nm}$, $A_{C}=$ the absorbance of control at $700 \mathrm{~nm}$.

\section{Ferric thiocyanate (FTC) assay}

FTC assay [13] was used to estimate the ability of the sample to inhibit decomposition of peroxides. Four different concentrations $(25,50$, 100 , and $200 \mu \mathrm{g} / \mathrm{ml}$ ) of the extract were prepared in Et. $4 \mathrm{ml}$ of this extract was added with $4.1 \mathrm{ml}$ of $2.5 \%$ ethanolic linoleic acid and $8 \mathrm{ml}$ of $0.2 \mathrm{mM}$ phosphate buffer and the above mixture was made up to $25 \mathrm{ml}$ with distilled water. This mixed solution was kept in a closed vial at a constant temperature of $40^{\circ} \mathrm{C}$ in oven for incubation. To the $0.1 \mathrm{ml}$ of the above solution, $9.7 \mathrm{ml}$ of $75 \%$ Et and $0.1 \mathrm{ml}$ of $30 \%$ ammonium thiocyanate were added. Exactly after $3 \mathrm{~min}, 0.1 \mathrm{ml}$ of $20 \mathrm{mM}$ ferrous chloride in $3.5 \% \mathrm{HCl}$ was added. The resulted red color absorption was read at $500 \mathrm{~nm}$ successively for consecutive 7 days with $24 \mathrm{~h}$ of interval.
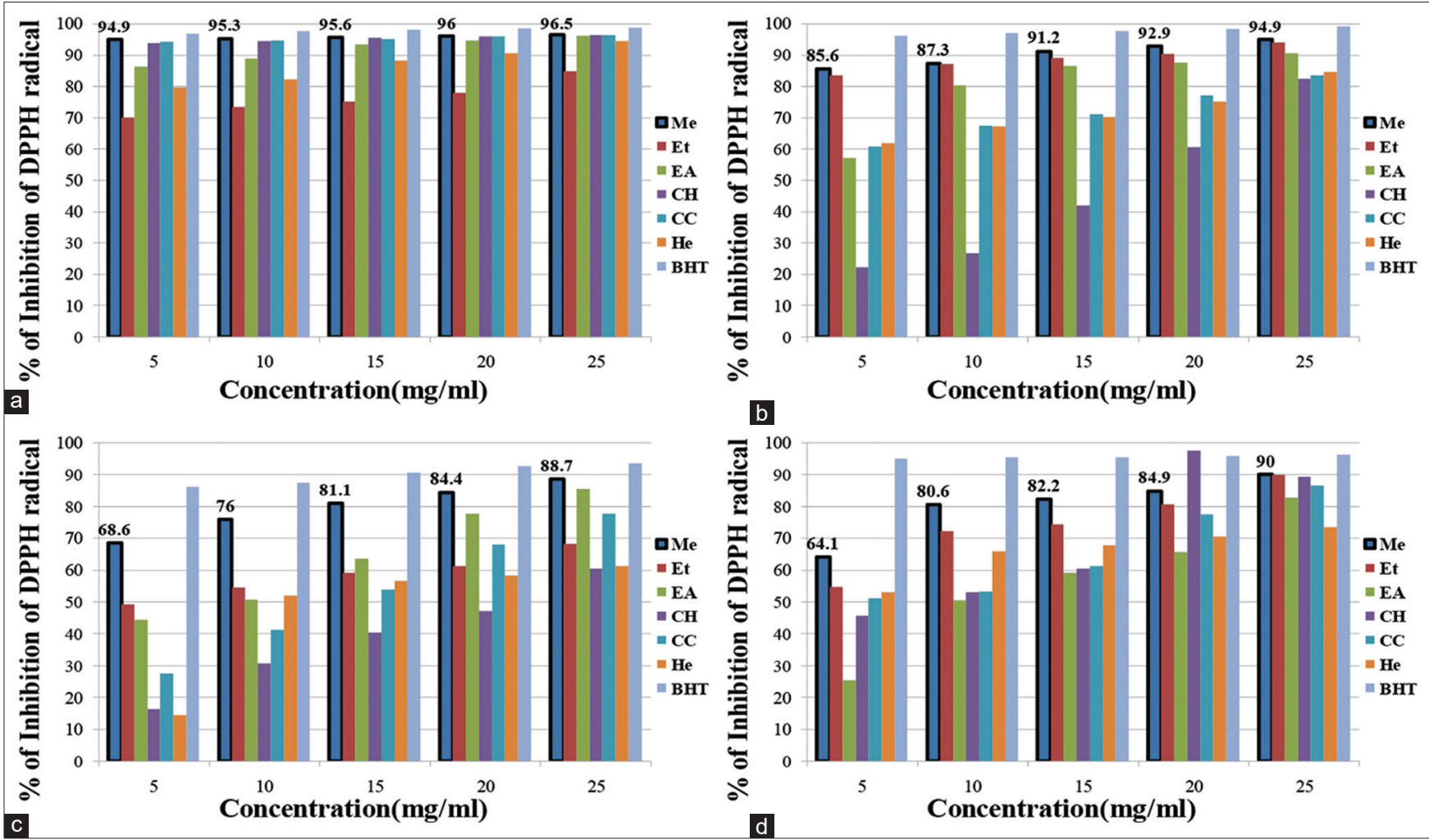

Fig. 2: DPPH assay of Pterocarpus santalinus L.f. Plant parts. *(a) Leaves (b) flowers (c) fruits (d) roots 
Distilled water was used as control and BHT was used as standard antioxidant reference. All solvent extracts of plant parts were assessed in this method and showed in graphical form in following figures from Figs. 4-7.

\section{$\beta$ - Carotene bleaching assay}

$\beta$ - Carotene bleaching assay was proposed by Taga et al. [14]. Three milligrams of $\beta$ - carotene were dissolved in $3 \mathrm{ml}$ of $\mathrm{Ch}, 20 \mathrm{mg}$ of linoleic acid, and $200 \mathrm{mg}$ of tween -40 were added. Then, Ch was removed by rota-evaporator at $50^{\circ} \mathrm{C}$ for few minutes and made up to $50 \mathrm{ml}$ with oxygenated water by mixing well to form an emulsion. One immediate reading of emulsion absorption was measured at $470 \mathrm{~nm}$. The emulsion prepared as above without $\beta$ - carotene was acted as blank. One milliliter of the $\beta$ - carotene linoleic acid emulsion was mixed with $1 \mathrm{ml}$ of extract sample in different concentrations $(50,125,250$, and $500 \mu \mathrm{g} / \mathrm{ml})$ and the above mixture was incubated at $50^{\circ} \mathrm{C}$ for $1 \mathrm{~h}$. Absorbance of that mixture was read at standard intervals of $15 \mathrm{~min}$ at $470 \mathrm{~nm}$ in UVvisible spectrophotometer. Here distilled water was used as control and
BHT was used as standard reference. All plant part extracts were tested in this method and the absorption values were represented in graphs from Figs. 8-11.

\section{RESULTS}

Table 1 gives the results of extraction efficiencies and yields. Table 2 indicates the results of phyochemical screening. Fig. 2 represents the DPPH assay results graphically. Fig. 3 represents the Relative reducing power (RRP) assay results graphically. Figs. 4 - 7 represent the Ferric ThioCyanate (FTC) assay results graphically. Figs. 8 - 11 represent the $\beta$ - Carotene bleaching assay results graphically.

\section{DISCUSSION}

Yields and extraction efficiencies

In Table 1, among six solvents Me and Et solvents showed high extraction efficiencies and yields. Me showed highest extraction efficiencies of $42 \%, 37 \%$, and $41.3 \%$ of leaf, flower, and root extracts with yields

Table 2: Qualitative phytochemical screening of Pterocarpus santalinus L.f. plant parts

\begin{tabular}{|c|c|c|c|c|c|c|c|c|c|c|c|c|c|c|c|c|c|c|c|c|c|c|c|c|}
\hline \multirow[t]{2}{*}{ Phytochemical tests } & \multicolumn{6}{|c|}{ Leaf Me extract } & \multicolumn{6}{|c|}{ Flower Me extract } & \multicolumn{6}{|c|}{ Fruit Me extract } & \multicolumn{6}{|c|}{ Root Me extract } \\
\hline & $* 1$ & 2 & 3 & 4 & 5 & 6 & 1 & 2 & 3 & 4 & 5 & 6 & 1 & 2 & 3 & 4 & 5 & 6 & 1 & 2 & 3 & 4 & 5 & 6 \\
\hline \multicolumn{25}{|l|}{ Alkaloids } \\
\hline Wagner's reagent & + & + & - & - & - & - & + & + & - & - & - & - & + & + & - & - & - & - & + & + & - & - & - & - \\
\hline Hager's reagent & + & + & - & - & - & - & + & + & - & - & - & - & + & + & - & - & - & - & + & + & - & - & - & - \\
\hline Dragendorff's reagent & + & + & - & - & - & - & + & + & - & - & - & - & + & + & - & - & - & - & + & + & - & - & - & - \\
\hline \multicolumn{25}{|l|}{ Carbohydrates and glycosides } \\
\hline Molisch's test & + & + & - & - & - & - & + & + & + & + & + & + & + & + & - & - & - & - & + & + & - & - & - & - \\
\hline Fehling's test & + & + & - & - & - & - & + & + & + & + & + & + & + & + & - & - & - & - & + & + & - & - & - & - \\
\hline Barfoed's test & + & + & - & - & - & - & + & + & + & + & + & + & + & + & - & - & - & - & + & + & - & - & - & - \\
\hline Benedict's test & + & + & - & - & - & - & + & + & + & + & + & + & + & + & - & - & - & - & + & + & - & - & - & - \\
\hline Borntrager's test & + & + & - & - & - & - & - & - & - & - & - & - & + & + & - & - & - & - & - & - & - & - & - & - \\
\hline Legal's test & + & + & - & - & - & - & - & - & - & - & - & - & + & + & - & - & - & - & - & - & - & - & - & - \\
\hline \multicolumn{25}{|l|}{ Saponins } \\
\hline Foam test & + & + & - & - & - & - & + & + & - & - & - & - & - & - & - & - & - & - & + & + & - & - & - & - \\
\hline \multicolumn{25}{|l|}{ Proteins and amino acids } \\
\hline Biuret reagent & + & + & - & - & - & - & + & + & + & + & + & + & - & - & - & - & - & - & + & + & - & - & - & - \\
\hline Ninhydrin reagent & + & + & - & - & - & - & - & - & - & - & - & - & - & - & - & - & - & - & - & - & - & - & - & - \\
\hline \multicolumn{25}{|l|}{ Phytosteroids } \\
\hline $\begin{array}{l}\text { Libermann's-Burchard's } \\
\text { test }\end{array}$ & + & + & + & + & + & + & + & + & + & + & + & + & - & - & - & - & - & - & + & + & - & - & - & - \\
\hline \multicolumn{25}{|l|}{ Fixed oils and fats } \\
\hline Spot test & - & - & - & - & - & - & - & - & - & - & - & - & - & - & - & - & - & - & - & - & - & - & - & - \\
\hline Saponification test & - & - & - & - & - & - & - & - & - & - & - & - & - & - & - & - & - & - & - & - & - & + & + & + \\
\hline \multicolumn{25}{|l|}{$\begin{array}{l}\text { Phenolic compounds and } \\
\text { flavonoids }\end{array}$} \\
\hline Ferric chloride test & + & + & - & - & - & - & + & + & + & + & + & + & + & + & - & - & - & - & + & + & - & - & - & - \\
\hline Gelatin test & + & + & - & - & - & - & + & + & + & + & + & + & + & + & - & - & - & - & + & + & - & - & - & - \\
\hline Lead acetate test & + & + & - & - & - & - & + & + & + & + & + & + & + & + & - & - & - & - & + & + & - & - & - & - \\
\hline Alkaline reagent & + & + & - & - & - & - & + & + & + & + & + & + & + & + & - & - & - & - & + & + & - & - & - & - \\
\hline $\mathrm{Mg}$ and $\mathrm{HCl}$ reduction & + & + & - & - & - & - & + & + & + & - & - & - & + & + & - & - & - & - & + & + & - & - & - & - \\
\hline \multicolumn{25}{|l|}{ Gums and mucilages } \\
\hline
\end{tabular}

*1 - Methanol, 2 - Ethanol, 3 - Ethyl acetate, 4 - Chloroform, 5 - Carbon tetrachloride, 6 - n- Hexane, (+) denotes positive, (-) denotes negative

Table 1: Yields of Pterocarpus santalinus L.f. plant parts and extraction efficiencies of the solvents

\begin{tabular}{|c|c|c|c|c|c|c|c|c|}
\hline \multirow[t]{2}{*}{ Solvent } & \multicolumn{4}{|c|}{ Yield (g) } & \multicolumn{4}{|c|}{ Extraction efficiency (\%) } \\
\hline & Leaf & Flower & Fruit & Root & Leaf & Flower & Fruit & Root \\
\hline $\mathrm{Me}$ & 210.0 & 185.0 & 140.0 & 206.5 & 42.0 & 37.0 & 28.0 & 41.3 \\
\hline Et & 147.0 & 178.0 & 197.5 & 206.5 & 29.4 & 35.6 & 39.5 & 41.3 \\
\hline EA & 44.5 & 53.5 & 40.5 & 23.5 & 8.9 & 10.7 & 8.1 & 4.7 \\
\hline $\mathrm{Ch}$ & 42.5 & 34.0 & 40.5 & 29.5 & 8.5 & 6.8 & 8.1 & 5.9 \\
\hline CC & 30.0 & 27.25 & 46.5 & 19.5 & 6.0 & 5.45 & 9.3 & 3.9 \\
\hline $\mathrm{He}$ & 26.0 & 22.25 & 35.0 & 14.5 & 5.2 & 4.45 & 7.0 & 2.9 \\
\hline
\end{tabular}




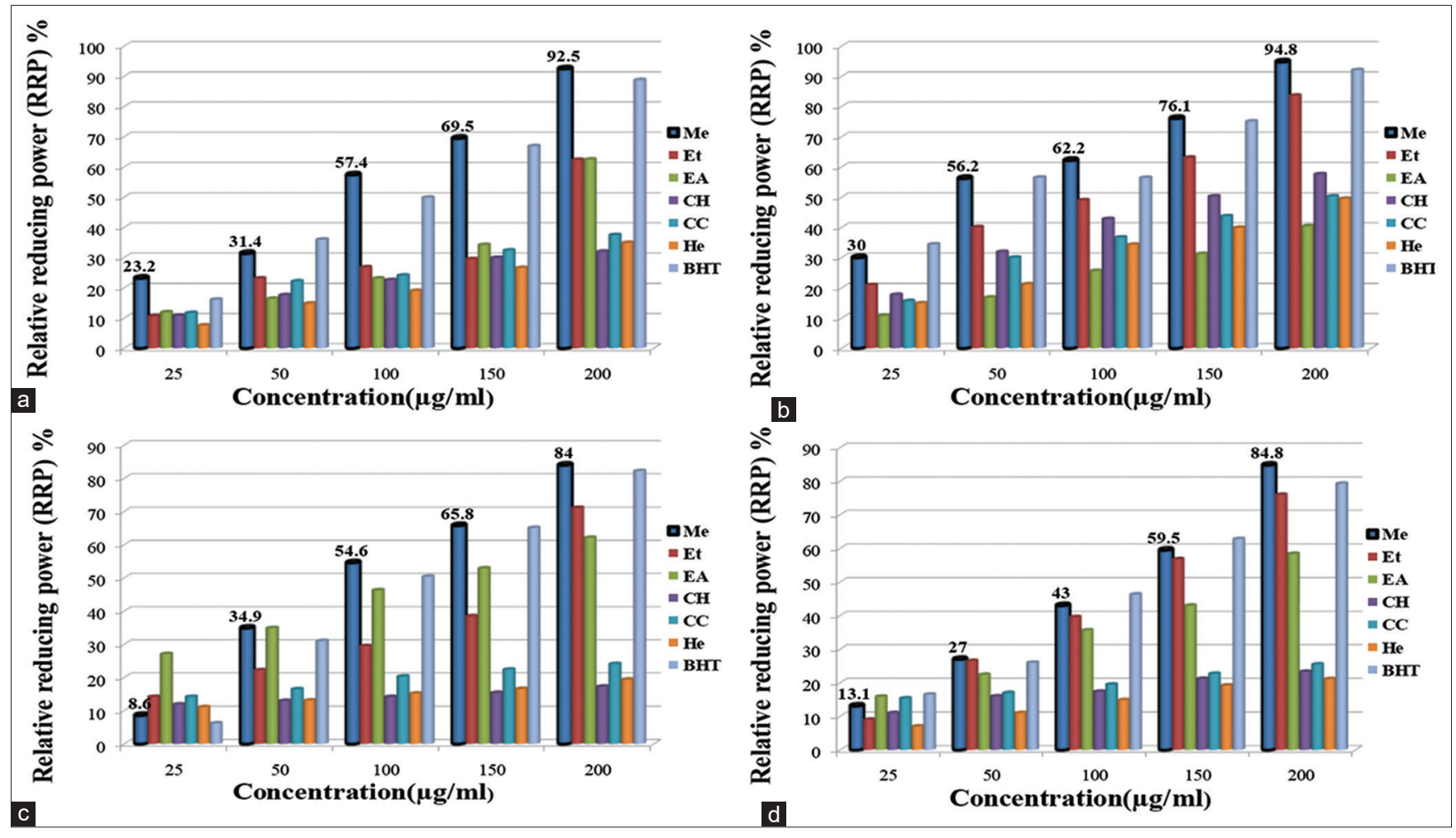

Fig. 3: Relative reducing power assay of Pterocarpus santalinus L.f. Plant parts. *(a) Leaves (b) flowers (c) fruits (d) roots

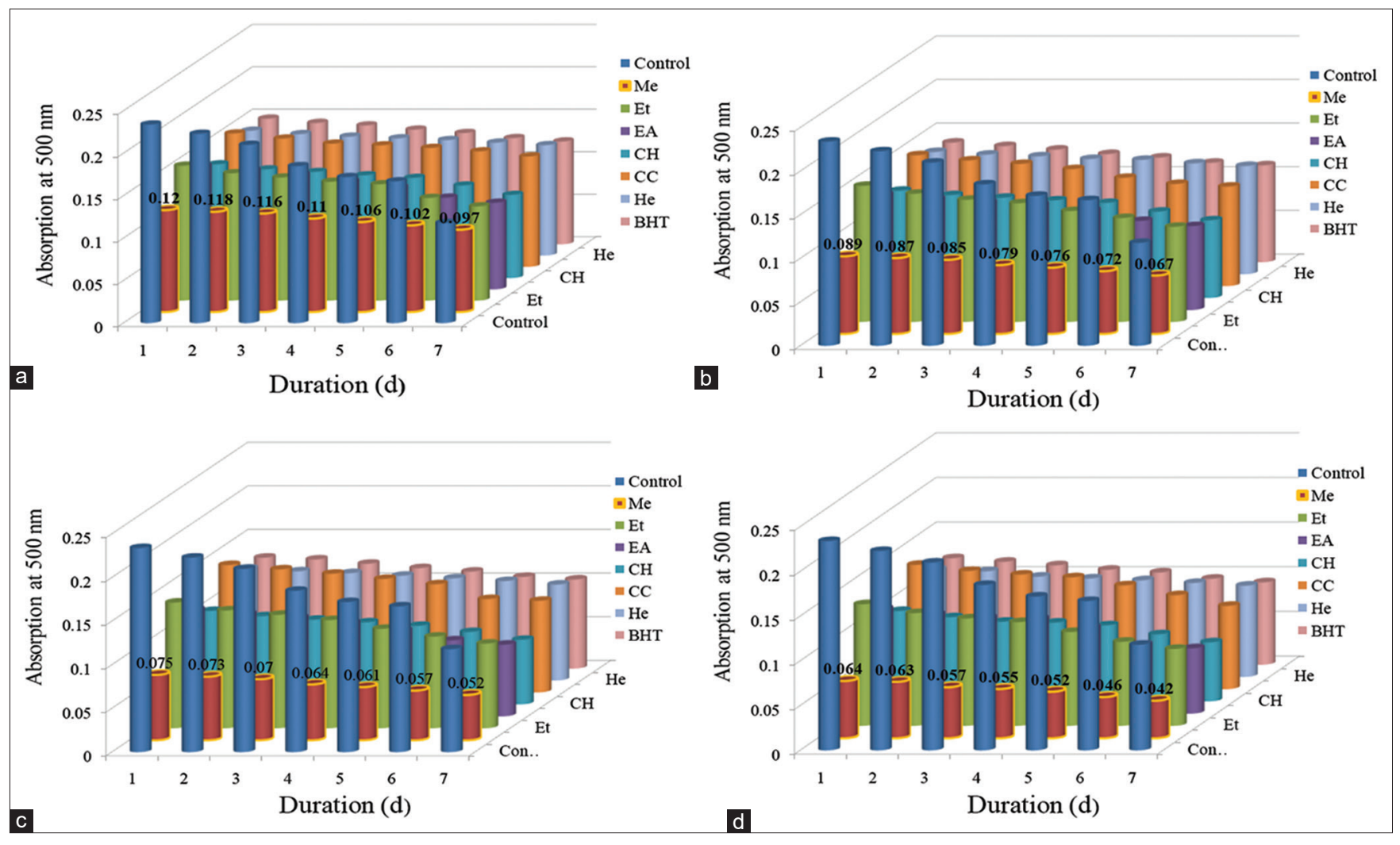

Fig. 4: Ferric thiocyanate assay of Pterocarpus santalinus L.f. leaves at different Conc. (a) $25 \mu \mathrm{g} / \mathrm{ml}$ (b) $50 \mu \mathrm{g} / \mathrm{ml}$ (c) $100 \mu \mathrm{g} / \mathrm{ml}$ (d) $200 \mu \mathrm{g} / \mathrm{ml}$

$210 \mathrm{~g}, 185 \mathrm{~g}$, and $206.5 \mathrm{~g}$, respectively, whereas Et showed extraction efficiencies of $39.5 \%$ and $41.3 \%$ of fruit and root extracts with yields $197.5 \mathrm{~g}$ and $206.5 \mathrm{~g}$, respectively.
Qualitative phytochemical screening

In qualitative phytochemical screening, the Me and Et extracts of all plant parts showed the existence of all types of primary and secondary 


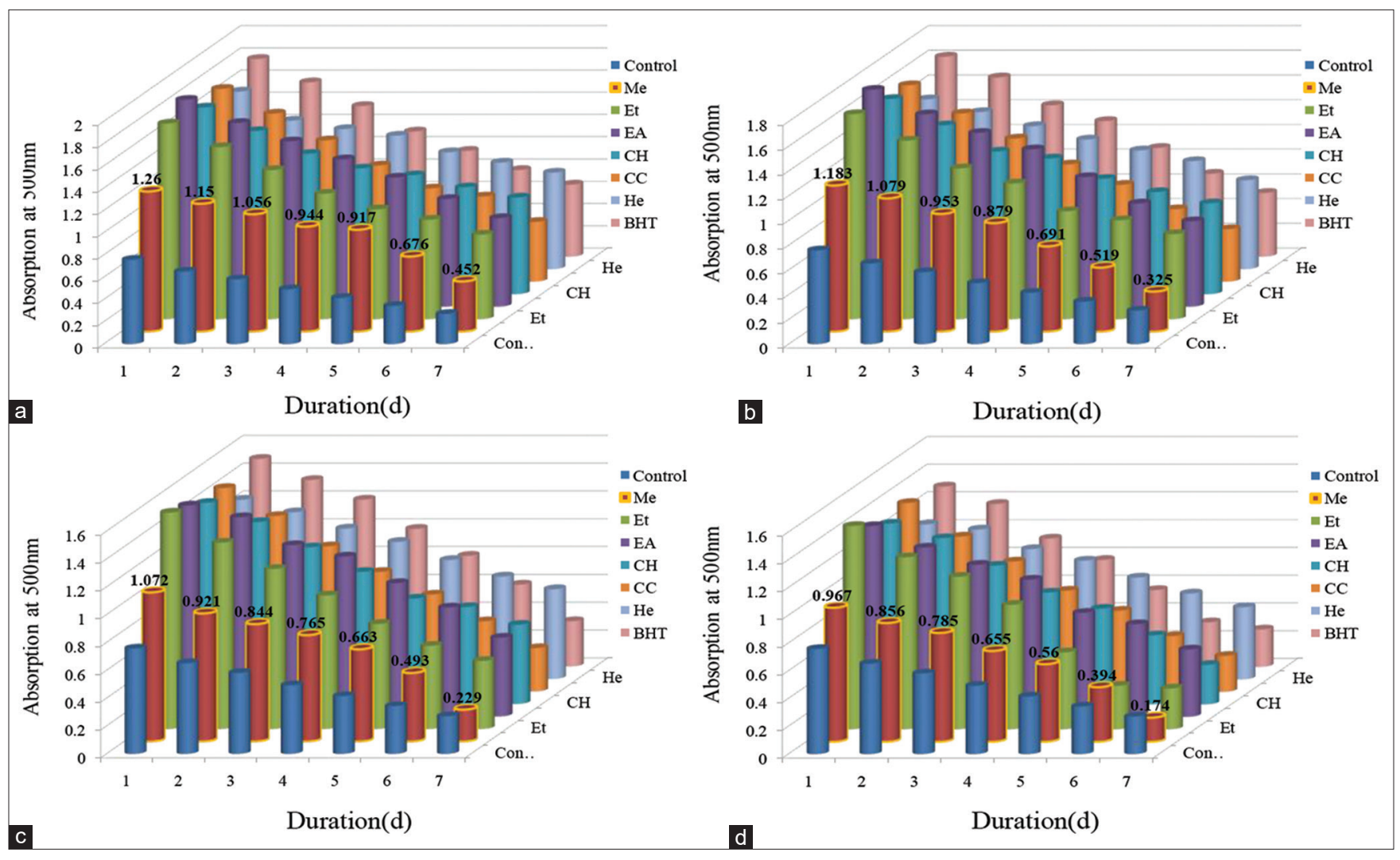

Fig. 5: Ferric thiocyanate assay of Pterocarpus santalinus L.f. flowers at different Conc. (a) $25 \mu \mathrm{g} / \mathrm{ml}$ (b) $50 \mu \mathrm{g} / \mathrm{ml}$ (c) $100 \mu \mathrm{g} / \mathrm{ml}$ (d) $200 \mu \mathrm{g} / \mathrm{ml}$

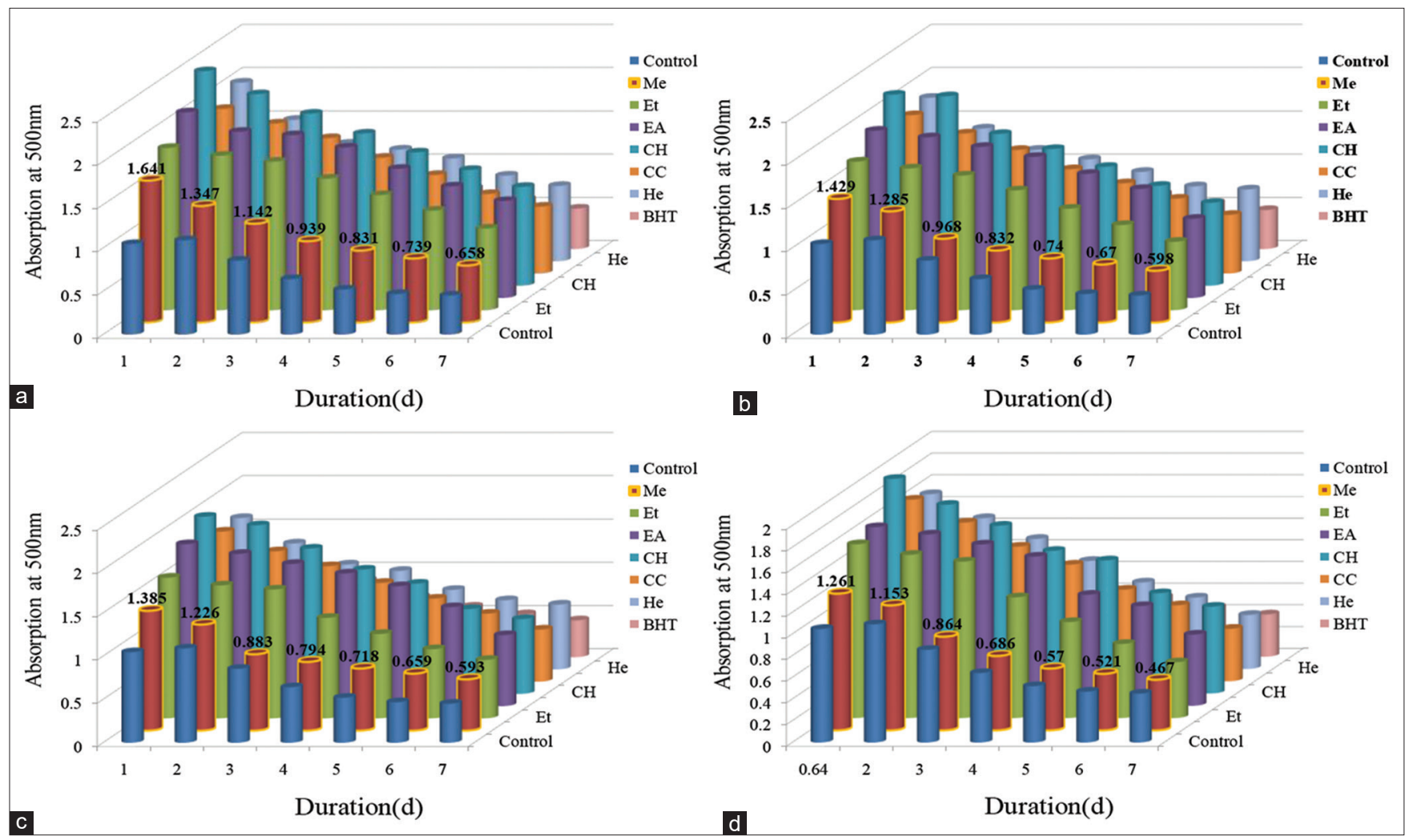

Fig. 6: Ferric thiocyanate assay of Pterocarpus santalinus L.f. fruits at different Conc. (a) $25 \mu \mathrm{g} / \mathrm{ml}$ (b) $50 \mu \mathrm{g} / \mathrm{ml}$ (c) $100 \mu \mathrm{g} / \mathrm{ml}$ (d) $200 \mu \mathrm{g} / \mathrm{ml}$ 


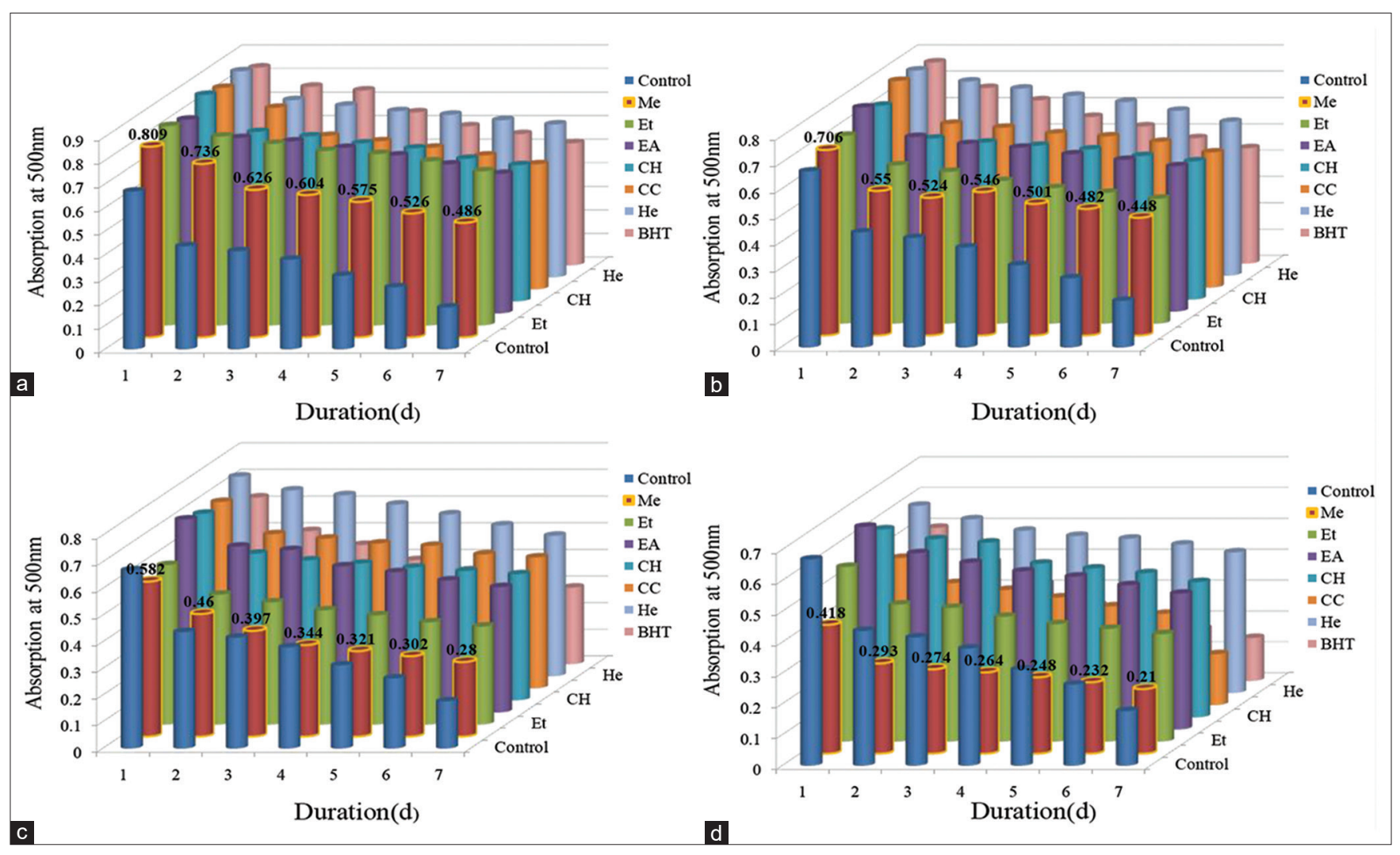

Fig. 7: Ferric thiocyanate assay of Pterocarpus santalinus L.f. roots at different Conc. (a) $25 \mu \mathrm{g} / \mathrm{ml}$ (b) $50 \mu \mathrm{g} / \mathrm{ml}$ (c) $100 \mu \mathrm{g} / \mathrm{ml}$ (d) $200 \mu \mathrm{g} / \mathrm{ml}$
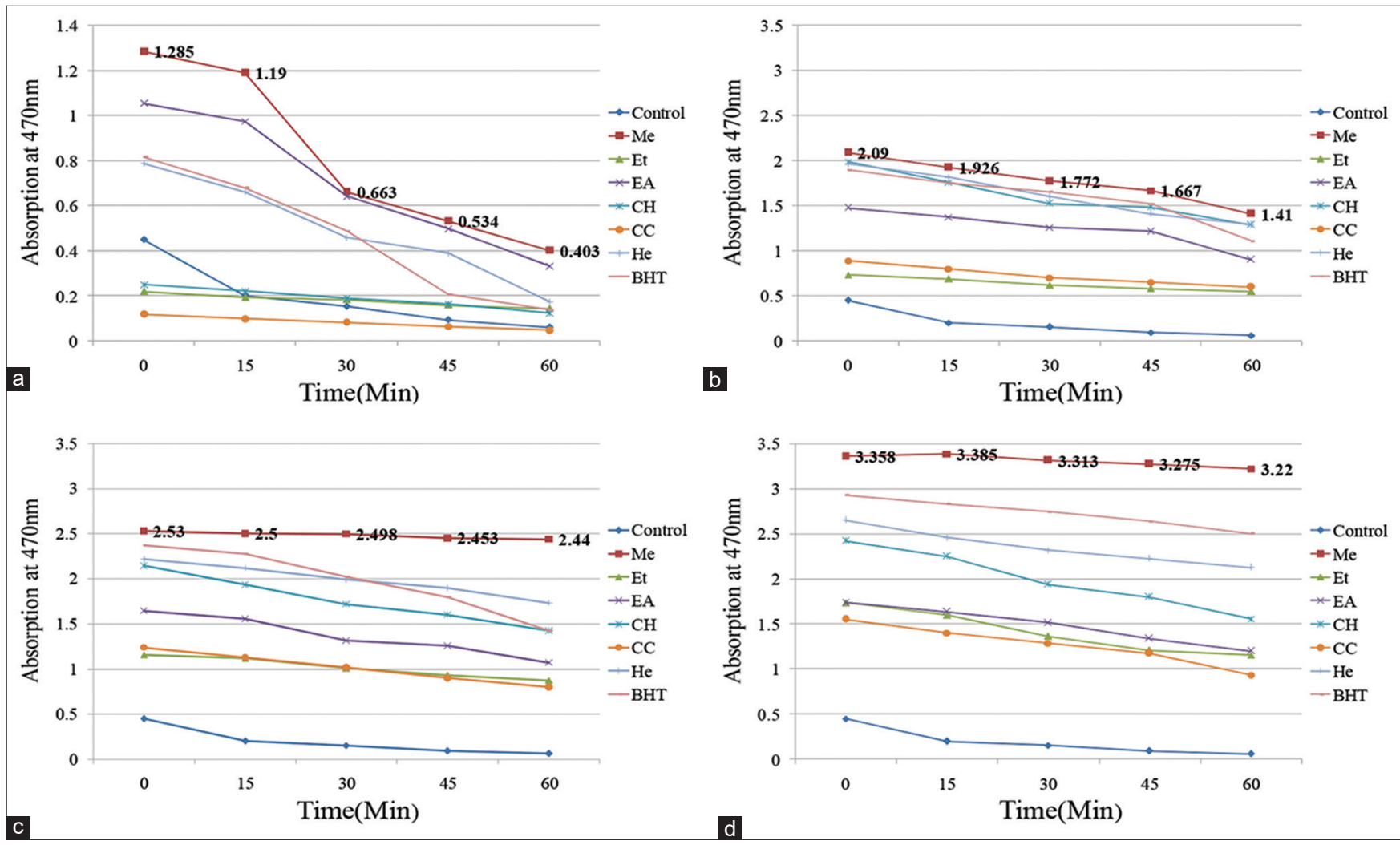

Fig. 8: $\beta$ - carotene bleaching assay of Pterocarpus santalinus L.f. leaves. (a) $50 \mu \mathrm{g} / \mathrm{ml}$ (b) $125 \mu \mathrm{g} / \mathrm{ml}$ (c) $250 \mu \mathrm{g} / \mathrm{ml}$ (d) $500 \mu \mathrm{g} / \mathrm{ml}$

metabolites, that is, alkaloids, carbohydrates, glucosides, saponins, proteins, phytosteroids, phenolics and flavonoids excluding fats, mucilages, gums, and fixed oils. All these phytochemicals were lacking in EA, Ch, CC, and He extracts of fruits, roots, and leaves apart from floral extracts, whereas saponins, proteins, and phytosteroids were missing in fruit extracts of all solvents. 


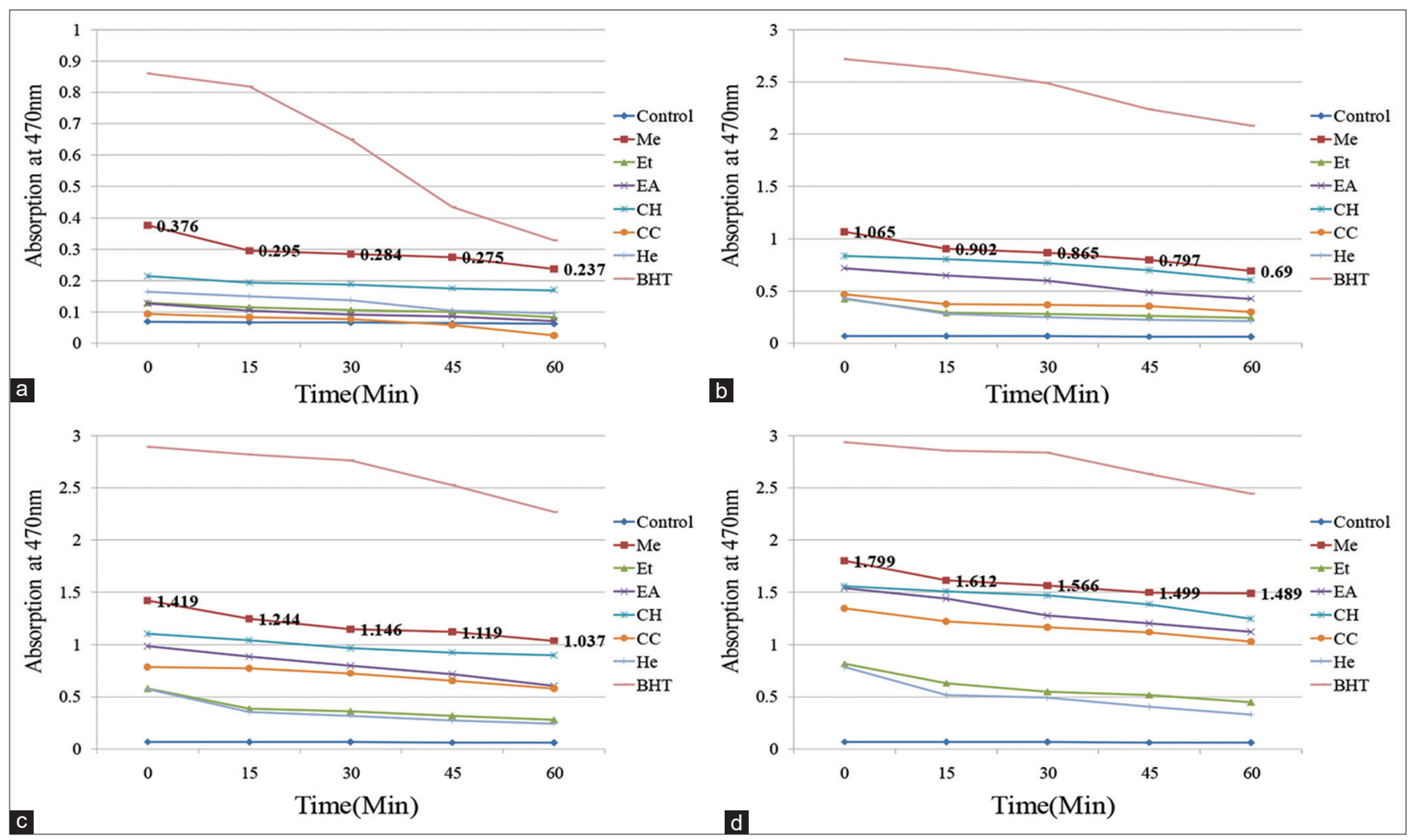

Fig. 9: $\beta$ - carotene bleaching assay of Pterocarpus santalinus L.f. flowers. (a) $50 \mu \mathrm{g} / \mathrm{ml}$ (b) $125 \mu \mathrm{g} / \mathrm{ml} \mathrm{(c)} 250 \mu \mathrm{g} / \mathrm{ml}$ (d) $500 \mu \mathrm{g} / \mathrm{ml}$
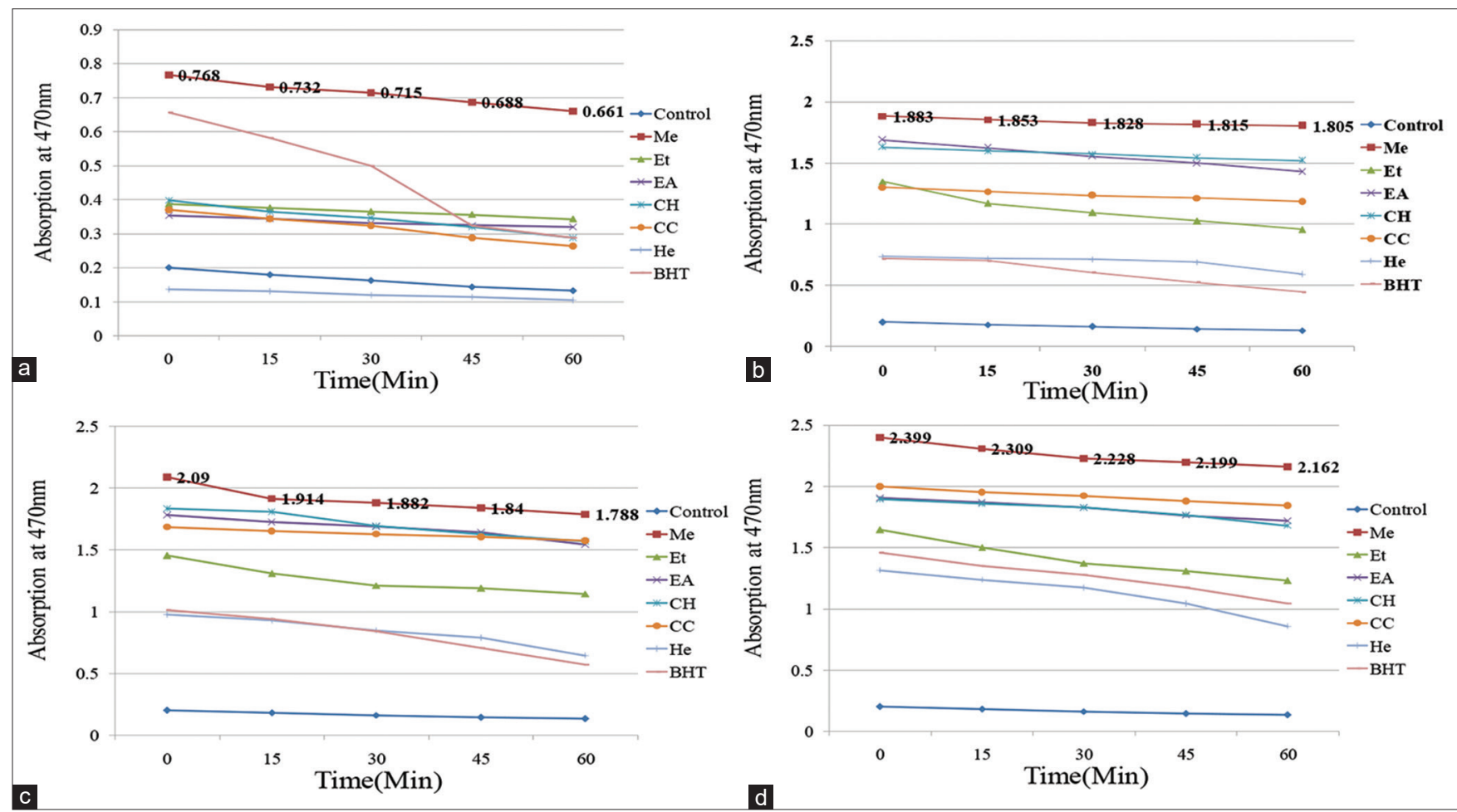

Fig. 10: $\beta$ - carotene bleaching assay of Pterocarpus santalinus L.f. fruits. (a) $50 \mu \mathrm{g} / \mathrm{ml}$ (b) $125 \mu \mathrm{g} / \mathrm{ml} \mathrm{(c)} 250 \mu \mathrm{g} / \mathrm{ml}$ (d) $500 \mu \mathrm{g} / \mathrm{ml}$

AA tests

DPPH RSA assay

The calculated percentages of DPPH RSA in formation of DPPH free radicals show that Me extract of all plant parts showed fair DPPH RSA amongst all six solvent extracts. At highest concentration $(25 \mathrm{mg} / \mathrm{ml})$,
Me extracts of leaf showed highest RSA (96.5\%), almost equal to the RSA of the standard BHT (98.7\%) in Fig. 2. As the concentration of extract increased, RSA of extract was also increased. DPPH assay showed that the AA of these extracts was probably due to the presence of phytochemicals which can acts as free radical scavengers. 


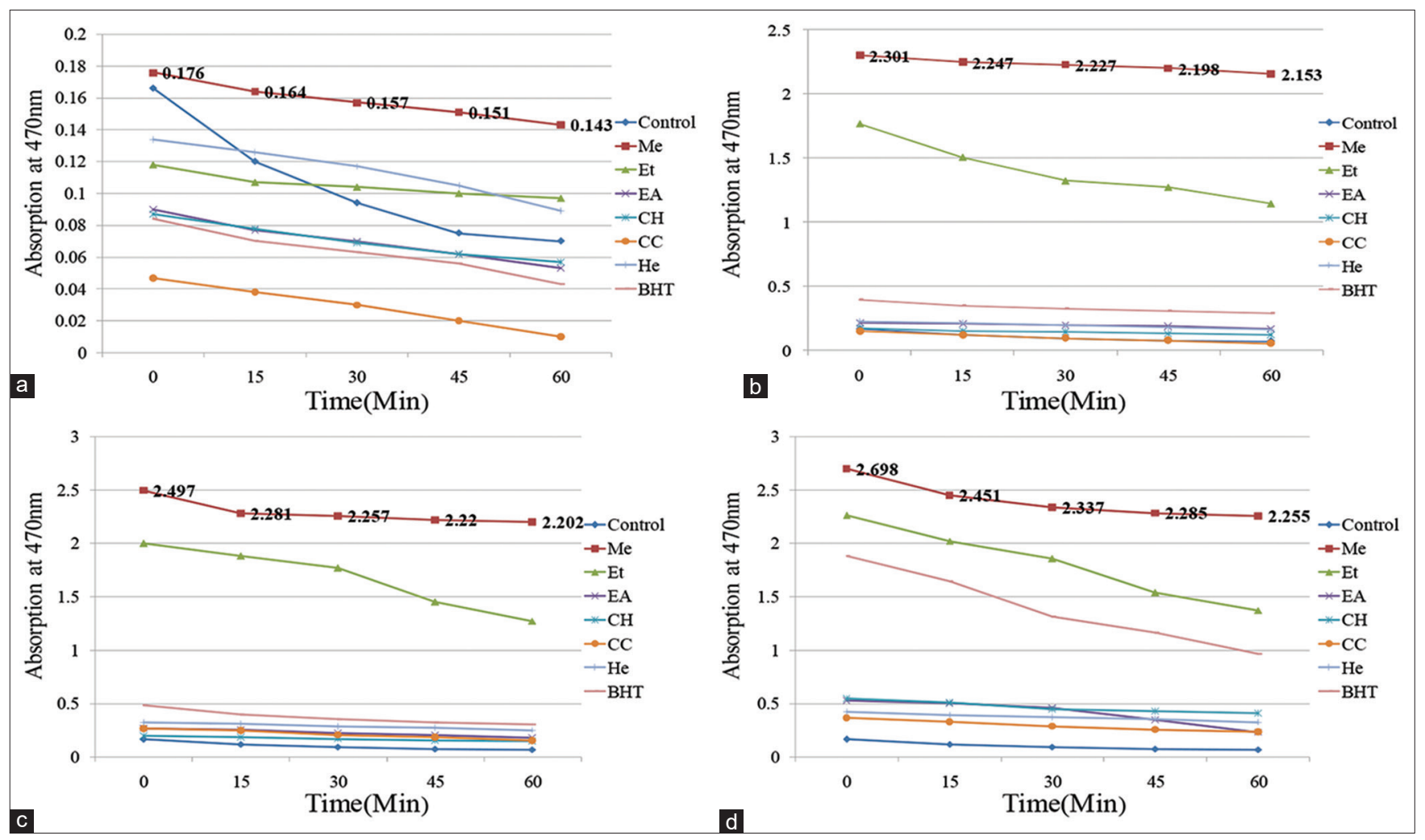

Fig. 11: $\beta$ - carotene bleaching assay of Pterocarpus santalinus L.f. roots. (a) $50 \mu \mathrm{g} / \mathrm{ml}$ (b) $125 \mu \mathrm{g} / \mathrm{ml}$ (c) $250 \mu \mathrm{g} / \mathrm{ml}$ (d) $500 \mu \mathrm{g} / \mathrm{ml}$

RRP assay

RRP assay was carried out on all solvent extracts of $P$. santalinus L.f. and the percentages of RRP of all extracts were shown in graphs. At highest concentration of $200 \mu \mathrm{g} / \mathrm{ml}$ concentration Me extracts of leaf and flower showed highest RRP of $92.5 \%$ and $94.8 \%$, which was greater than RRP of BHT, that is, $88.8 \%$ in Fig. 3. Me extracts of all plant parts showed good RRP compared to other solvent extracts. The RRP of the extract was increased as the concentration of the extract was increased.

\section{FTC assay}

In FTC assay, the AA of extracts which inhibits the degradation of peroxides was estimated. In this test, Me solvent extracts of all the plant parts showed better FTC than all other solvent extracts. Here lower absorption values indicate the highest FTC potential of the sample. Me floral extracts showed lowest absorption values indicating the highest FTC potential than standard BHT. As the concentration of the extract was increased, the FTC of the extract was also increased.

\section{$\beta$ - Carotene bleaching assay}

$\beta$ - Carotene bleaching assay was used to evaluate the AA of the extracts against oxidation of $\beta$ - Carotene. The Me extracts of all plant parts showed better activity than others solvent extracts. And also Me extracts of all plant parts except floral extract (Fig. 9) showed higher $\beta$-carotene bleaching activity than BHT. High absorption values specify high $\beta$-carotene bleaching activity. As the concentration of extract was raised, the $\beta$-Carotene bleaching activity of the extract was also increased.

\section{CONCLUSION}

The phytochemical investigation on P. santalinus L.f. leaves, flowers, fruits, and roots showed that Me and Et extracts of all plant parts showed the presence of almost all phytochemicals except oils, gums, mucilages, and fats. The Me extracts of all plant parts showed good $\mathrm{AA}$ in four types of antioxidant assays. By this we can conclude that the presence of different phytochemicals has attributed the natural antioxidant potential to these extracts. Further studies on Me extracts of leaves and flowers of this plant are suggested for isolating these phytochemicals, which might be the reason for AA better than synthetic standards.

\section{ACKNOWLEDGMENT}

The authors are grateful to the Director, JNTUA OTRI, Ananthapuramu district, A.P., India, for permitting us to do our research and providing the lab facilities to carry out this course of work.

\section{AUTHORS' CONTRIBUTIONS}

Dr. NBL Prasad sir has contributed in procuring the plant parts, also guided and supervised the entire research work with his valuable experience and suggestions.

Bharathi Bestha has done the extraction, qualitative phytochemical screening, and antioxidant assessments of $P$. santalinus L.f. plant parts.

\section{CONFLICTS OF INTEREST}

The authors declare that they have no conflicts of interest.

\section{AUTHORS' FUNDING}

Bharathi Bestha has funded for the whole research work done.

\section{REFERENCES}

1. Kumar JK, Prasad AG, Richard SA. In vitro antioxidant activity and preliminary phytochemical analysis of medicinal Legumes. J Pharm Res 2012;5:3059-62.

2. Guleria S, Tiku AK, Singh G, Koul A, Gupta S, Rama S, et al. In vitro antioxidant activity and phenolic contents in methanol extracts from medicinal plants. J Plant Biochem Biotechnol 2013;22:9-15.

3. Arokiyaraj A, Perinbam K. Antifungal activity of Pterocarpus santalinus-an in vitro study. Biomed Pharmacol J 2010;3:107-10.

4. Wendakoon C, Calderon P, Gagnon D. Evaluation of selected medicinal plants extracted in different ethanol concentrations for antibacterial 
activity against human pathogens. J Med Act Plants 2012;1:60-8.

5. Marinova D, Ribarova F, Atanassova $\mathrm{M}$. Total phenolics and flavonoids in Bulgarian fruits and vegetables. J Univ Chem Technol Metall 2005;40:255-60

6. Chanwitheesuk A, Teerawutgulrag A, Rakariyatham N. Screening of antioxidant activity and antioxidant compounds of some edible plants of Thailand. Food Chem 2005;92:491-7.

7. Longo L, Vasapollo G. Extraction and identification of anthocyanins from Smilax aspera L. berries. Food Chem 2006;94:226-31.

8. Harborne JB, Williams CA. Advances in flavonoid research since 1992. Phytochemistry 2000;55:481-504.

9. Raaman N. Phytochemical Techniques. India: New India Publishing Agency; 2006.

10. von Gadow A, Joubert E, Hansmann CF. Comparison of antioxidant activity of aspalathin with that of other plant phenols of rooibos tea (aspalathin linearis), $\alpha$-tocopherol, BHT and BHA. J Agric Food Chem 1997;45:632-8

11. Yen GC, Duh PD. Scavenging scavenging effect of methanolic extracts of peanut hulls on free radical and active-oxygen species. J Agric Food Chem 1994;42:629-32.

12. Oyaizu M. Studies on products of the browning reaction: Antioxidative activities of products of browning reaction prepared from glucosamine. Jpn J Nutr 1986;44:307-15.

13. Osawa T, Namiki M. A novel type of antioxidant isolated from leaf wax of eucalyptus leaves. Agric Biol Chem 1981;45:735-9.

14. Taga MS, Miller EE, Pratt DE. Chia seeds as a source of natural antioxidants. J Am Oil Chem Soc 1984;61:928-31. 